\title{
The Benzú rockshelter: a Middle Palaeolithic site on the North African coast
}

\author{
José Ramos ${ }^{\mathrm{a}, *}$, Darío Bernal ${ }^{\mathrm{a}}$, Salvador Domínguez-Bella ${ }^{\mathrm{b}}$, David Calado ${ }^{\mathrm{c}}$, Blanca Ruiz ${ }^{\mathrm{d}}$, \\ María J. Gill ${ }^{\mathrm{d}}$, Ignacio Clemente ${ }^{\mathrm{e}}$, Juan J. Durán ${ }^{\mathrm{f}}$, Eduardo Vijande ${ }^{\mathrm{a}}$, Simón Chamorro ${ }^{\mathrm{g}}$ \\ a Departamento de Historia, Geografía y Filosofía. Facultad de Filosofía y Letras. Universidad de Cádiz, 11003 Cádiz, Spain \\ ${ }^{\mathrm{b}}$ Departamento de Ciencias de la Tierra. Facultad de Ciencias. Universidad de Cádiz, Puerto Real, Cádiz, Spain \\ ${ }^{\mathrm{c}}$ Instituto Português de Património Arquitectónico. Faro, Portugal \\ duniversidad de Alcalá de Henares. Alcalá de Henares, Madrid, Spain \\ e Institució Milá i Fontanals, CSIC. Barcelona, Spain \\ ${ }^{\mathrm{f}}$ Instituto Geológico y Minero de España. Madrid, Spain \\ ${ }^{\mathrm{g}}$ Instituto de Estudios Ceutíes. Ceuta, Spain
}

\section{A R T I C L E I N F O}

\section{Article history:}

Received 29 May 2007

Received in revised form 15 July 2008

Accepted 1 August 2008

\begin{abstract}
A B S T R A C T
The rockshelter of Benzú has a Middle-Upper Pleistocene stratigraphic sequence with ten levels, seven with evidence of human occupation. Speleothems have been dated by U/Th and the sedimentary levels by OSL and TL, showing that the sequence extends from $250 \mathrm{ka}$ to $70 \mathrm{ka}$. In this paper, we summarise the results of geomorphology, chronostratigraphy and excavation, and provide preliminary results on the pollen, faunal and lithic remains. The location of the site on the North African coast of the Strait of Gibraltar offers the potential to throw light on contacts and relationships between prehistoric communities in North Africa and the South Iberian Peninsula, for whom the Strait may have served as a bridge rather than a barrier.
\end{abstract}

(c) 2008 Elsevier Ltd. All rights reserved.

\section{Introduction}

The Benzú rockshelter is located on the North African coastline of the Strait of Gibraltar (Fig. 1). It was discovered during an archaeological survey of Ceuta carried out by a team from the University of Cádiz (Bernal, 2002; Bernal et al., 2003, 2005). The site is situated in a geographically strategic location directly facing the caves of Gibraltar (Finlayson et al., 2001, 2006), and this allows a direct comparison between data from southern Europe and North Africa. The archaeological sequence at Benzú provides data on the natural environment and ecology of the surrounding region during the Middle and Upper Pleistocene (Ramos and Bernal, 2006). The lithic technology, attributed to Mode 3, Mousterian, shows many similarities with that found in the southern Iberian Peninsula (Ramos et al., 2006a). Traditionally, any hypotheses concerning possible entry into Europe through this region by Palaeolithic populations have been disregarded, but this probably reflects the fact that western Asia has benefited from much more extensive investigation (Gamble, 2001; Stringer and Gamble, 1993; Mellars, 2006). One of the main objectives of our work is to address the issue of possible contact between hunter-gatherer populations on either side of the Strait of Gibraltar during the Middle and Upper

\footnotetext{
* Corresponding author. Tel.: +34 956 015500; fax: +34 956015501.

E-mail address: jose.ramos@uca.es (J. Ramos).
}

Pleistocene. Important advances have been achieved in palaeoecological studies at Benzú, with the focus now shifting to the archaeology and lithic technology. Particular attention will be given to the sourcing of raw materials, as well as to analyses of the technology and functional of the lithic artefacts.

\section{The Geographical and Ecological Context}

The site is situated within an Atlantic-Mediterranean environmental context and within a geological zone comprising two important mountain ranges: the Rif and the Betic, which enclose the Alboran Sea, creating a tectonic belt known as the 'Gibraltar Arc'. Prominent features are the limestone massif of Gebel Musa, which with the Rock of Gibraltar forms the "Pillars of Hercules", and Gebel Fahies (Fig. 1). The area is structurally complex with intensive folding accompanied by metamorphism and large overthrust sheets, and there are similar geological features on both the southern European and North African side.

The Benzú rockshelter is $230 \mathrm{~m}$ from the present coastline at $61 \mathrm{~m}$ asl, next to the Arroyo del Algarrobo within the Bay of the Ballenera (Fig. 2) (Garriga and Tarradell, 1951). It is located within the Beni Mesala geological system adjacent to the quarry at Benzú, on the western side of Ceuta. Characteristic materials can be found in its immediate surroundings: bluish grey phyllites, schists and quartzites, as well as important occurrences of Middle Triassic dolomite and bluish grey limestone. The morphology of the 


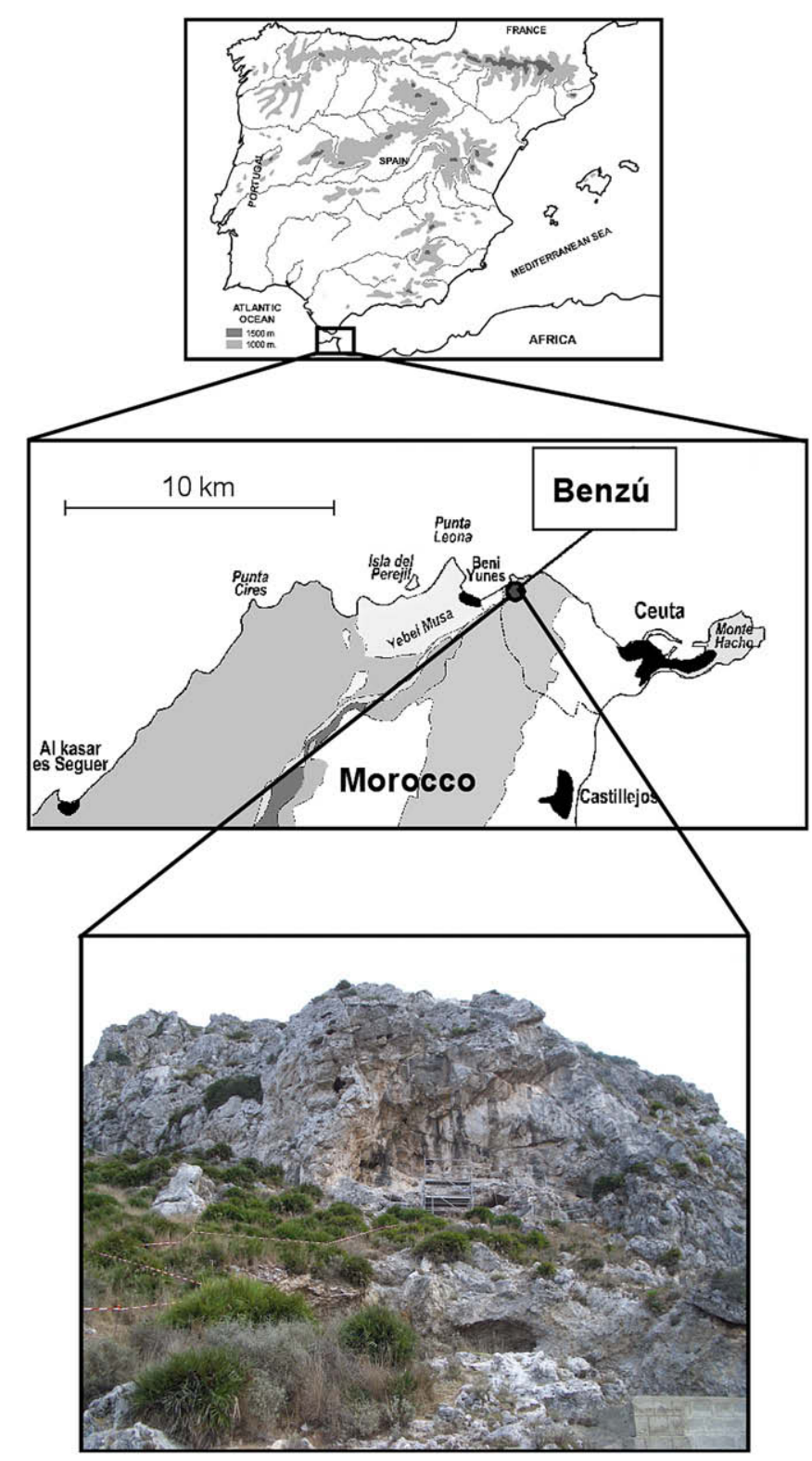

Fig. 1. Location map.

rockshelter is similar to the neighbouring cliff at Ras Yaún (Cape Leona). The latter is dated to Oxygen Isotope Stage (OIS) 5-7 (Rodríguez-Vidal and Cáceres, 2005), while morphotectonic comparison of both shores of the Strait of Gibraltar (Gebel Musa and Gibraltar) suggests that the formation of the Benzú rockshelter is slightly older, belonging to level MTU-4 of Rodríguez-Vidal et al. (2004), with a date of ca $250 \mathrm{ka}$.

\subsection{Description of the rockshelter and available resources}

The Benzú rockshelter is created in a dolomitic formation, and the morphology is very abrupt, with some rock walls being almost vertical. A large section of the shelter ceiling has collapsed, and blocks measuring on average ca $16 \times 6 \mathrm{~m}$ are scattered in front of the shelter. In the southeastern corner of the rockshelter there is a small cave measuring $5.4 \times 4.6 \mathrm{~m}$ wide, with a very small entrance and a floor area of ca $14 \mathrm{~m}^{2}$. It has two separate circular galleries each less than $1 \mathrm{~m}$ in height, both of which have sandy deposits less than $1 \mathrm{~m}$ deep. Two stratigraphic levels have been excavated within these deposits and attributed to the Neolithic.

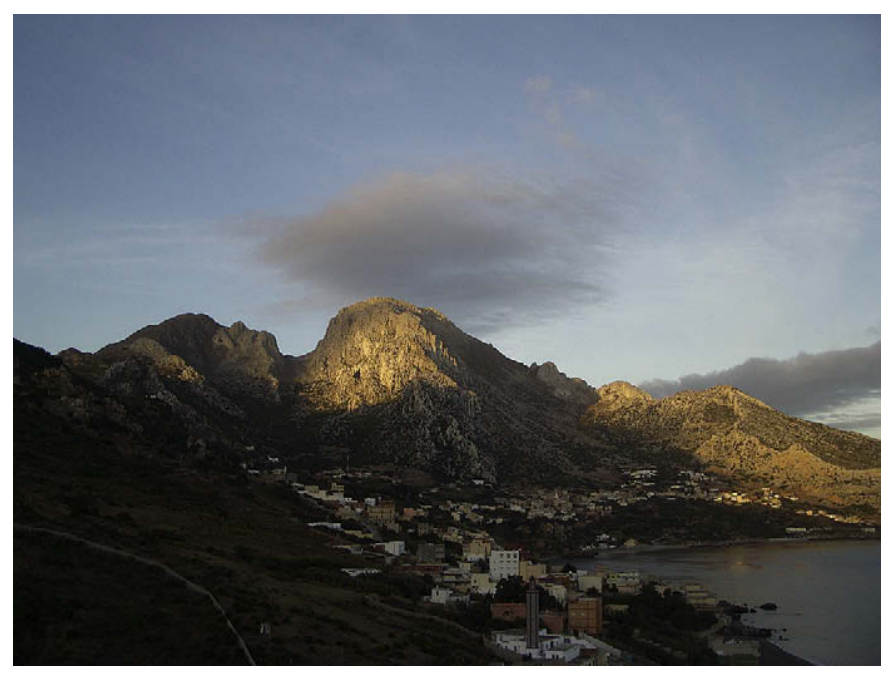

Fig. 2. View of Benzú rockshelter in its geographic setting.

The archaeological deposit within the main rockshelter comprises carbonated breccia, speleothem formations and cave wall collapse, with an area of $61.1 \mathrm{~m}^{2}$, and a maximum depth of $\sim 5.5 \mathrm{~m}$. Geological studies of sedimentation (Durán, 2003) have identified 10 stratigraphic levels (numbered from the base upwards). Levels 1-7 contain evidence of human occupation, with lithic artefacts, bone and shell. The shelter has been subjected to typical natural processes such as ceiling collapse and sedimentation which reflect different climatic conditions and slope evolution. Recent studies on the micromorphology and bio-erosive features have shown that a major phase of marine erosion took place before any human occupation, predating OIS 9 (Abad et al., 2007).

The sediments show a sequence of climatic conditions (cycles). Levels 1-3 (Lower Cycle), 4-6 (Middle Cycle), and 7-8 (Upper Cycle) (Fig. 3) constitute episodes of accumulation, representing generally warm and humid conditions. Solifluction intrusions indicate episodes of colder climate. Level 9 is a breccia resulting from collapse of the shelter and is also associated with cold conditions. Levels $3 \mathrm{~b}$ and 10 are flowstones, attributed to episodes of warm and humid climate (Durán, 2003).

The surrounding area offered numerous resources: marine (Ballenera Beach), terrestrial animals, plants and stone raw materials (Arroyo del Algarrobo), dolomite from Gebel Musa and Gebel Fahies, and freshwater from springs and underground wells (demonstrated by the presence of travertines in Beni Yunes village (see Fig.1)).

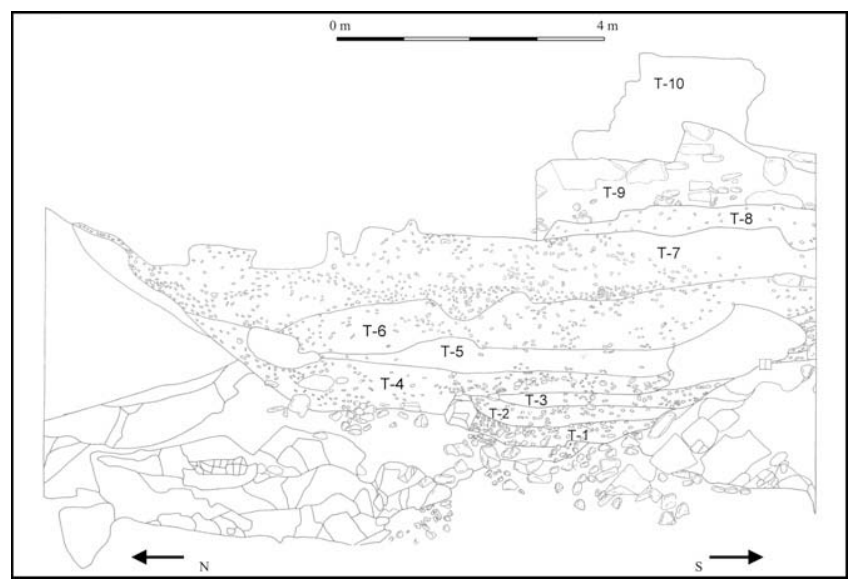

Fig. 3. Stratigraphic section of Benzú rockshelter. 


\subsection{Chronology}

U/Th was used to date the speleothem levels (Durán, 2003, 2004) and OSL/SAR to date the detritic sediments (Bateman and Calado, 2003; Calado, 2006). The U/Th dates were processed by the IGME laboratory in Madrid and by the Instituto Jaime Almera-CSIC in Barcelona, and the OSL dates were processed by the University of Sheffield. A new experimental technique of dating speleothem and breccia using TL has also been carried out for comparison at the Universidad Autónoma de Madrid (Benéitez et al., 2004).

The results from $\mathrm{U} / \mathrm{Th}$ and OSL provide a consistent chronology for the whole sequence. Two U/Th dates of $70 \mathrm{ka}$ are available for the speleothem formation which seals the stratigraphic sequence. Level $3 \mathrm{~b}$ is a thin speleothem layer that covers part of level 3 and is dated by U/Th to $173 \pm 10 \mathrm{ka}$. The OSL dates refer to the top of level 5 (Shfd020136: $168 \pm 11 \mathrm{ka}$ ) and level 2 (Shfd020135: $254 \pm 17 \mathrm{ka}$ ) (see Table 1).

These dates indicate that the whole sequence is older than $70 \mathrm{ka}$, with the earliest evidence of human occupation dated at ca $250 \mathrm{ka}$. Human occupation was intermittent and interspersed with periods of abandonment, the latter associated, in some cases, with episodes of geological instability associated with the partial collapse of the ceiling and mouth of the shelter.

The approximate minimum and maximum dates for each episode of accumulation indicate large variations in the rate of formation of the different layers and by implication the intensity and type of occupation of the shelter during the different phases. Level 3, for example, formed between $254 \pm 17$ and $173 \pm 10 \mathrm{ka}$, a period of approximately $80 \mathrm{ka}$. In contrast, levels 4 and 5 were formed between $173 \pm 10$ and $168 \pm 11 \mathrm{ka}$, only a few thousand years in comparison (Table 1). One should clearly bear in mind these differences in evaluating the archaeological richness of level 3 in comparison with the archaeological material recovered from levels 4 and 5 .

\section{Methods}

\subsection{Excavation}

The archaeological campaigns to date have concentrated on the study and definition of the geoarchaeological features of the deposit. All the lithic, bone and shell material excavated from level 7 during the 2002 campaign was recorded in situ. We also carried out an archaeological sounding of the full sequence, excavating levels 7 and 6 in 2003, levels 5 and 4 in 2004, and levels 3, 2 and 1 in 2005.

Most of the occupational levels are made up of calcareous breccias. In some cases, as in level 7, these are very compact and hard, sometimes cemented and with large rocks at the base. We

Table 1

Stratigraphy, types of sediments and dates of the Benzú rockshelter

\begin{tabular}{|c|c|c|c|}
\hline Level & Type of sediment & Chronology & Notes \\
\hline 10 & Upper Speleothem & (Th/U) IGM: $70 \mathrm{ka}$ & Seals the sequence \\
\hline 9 & Breccia with clasts & & \\
\hline 8 & Micrite & & \\
\hline 7 & $\begin{array}{l}\text { Breccia cemented } \\
\text { with blocks }\end{array}$ & & \\
\hline 6 & Micritic mud & & \\
\hline 5 & $\begin{array}{l}\text { Breccia, sands } \\
\text { and muds }\end{array}$ & $\begin{array}{l}\text { (OSL) Shfd020136: } \\
168 \pm 11 \mathrm{ka}\end{array}$ & $\begin{array}{l}\text { OSL from the upper } \\
\text { part of this level }\end{array}$ \\
\hline 4 & Breccia and muds & & \\
\hline $3 b$ & Speleothem & (Th/U) IGM: $173 \pm 10 \mathrm{ka}$ & Thin flowstone \\
\hline 3 & Micritic mud & & \\
\hline 2 & Breccia and muds & $\begin{array}{l}\text { (OSL) Shfd 020135: } \\
254 \pm 17 \mathrm{ka}\end{array}$ & $\begin{array}{l}\text { OSL from the upper } \\
\text { part of this level }\end{array}$ \\
\hline 1 & Breccia & & \\
\hline 0 & Substrate & & \\
\hline
\end{tabular}

experimented with various techniques to excavate the breccia, including the use of hammers and chisels, as well as different kinds of acids (hydrochloric and acetic). But these were ineffective and we resorted to a system of wedges and counter-wedges to remove blocks of deposit, techniques known to palaeontologists and stone masons but not usually applied to archaeological excavations. We took an area one metre square, divided it into a grid of $25 \mathrm{~cm}$ by $25 \mathrm{~cm}$ blocks, drilled vertical holes along the boundary of each block and horizontally beneath them, using a pneumatic drill, and extracted each block using steel wedges and hammers, with further drilling as necessary. Each block was then taken to the laboratory, and taken apart with hammers, small chisels and pneumatic microhammers with different percussion bits. Once the stratigraphic sequence is fully established, we aim to expand the area of excavation to better understand the association between features and archaeological artefacts and the spatial distribution of activities.

\subsection{Palynology and anthracology}

The samples for pollen were treated according to methods described by Coûteaux (1977) and Moore et al. (1991), followed by pollen concentration with Thoulet heavy liquid (Goeury and De Beaulieu, 1979). TILIA and TILIA-GRAPH (Grimm, 1992) were used for the construction of the pollen diagrams including percentages of tree, shrub, and herbaceous pollen. Pollen assemblage zones were based on the visual inspection of changes in at least two ecologically significant pollen taxa. Anthracological analysis of charcoal is still in progress (Uzquiano, 2006), but the presence of Erica and Leguminosae in level 4 has so far been confirmed.

\subsection{Fauna}

Animal bones are very abundant and the assemblage comprises medium and small-sized prey suggesting an intensive human activity. The study of the bones, however, is complicated by the brecciated character of the deposit, which has so altered the material as to render taxonomic classification to the level of genus or species almost impossible. Faunal remains are currently being studied by Alfonso Arribas (IGME, Spain) and Carlos Díez (Universidad de Burgos). The recovery of the remains from the breccia matrix involves intensive laboratory work. The bones have to be extracted, refitted and consolidated before they can be analysed. For this we use both mechanical techniques, including hammers, ultrasound and sand-blasting, and controlled chemical techniques, such as dissolving in non-destructive acidic solutions.

\subsection{Lithic technology}

The objectives of the lithic analysis are to provide information on mode of production of stone tools and activities carried out in the site, with emphasis on raw materials, knapping and reduction techniques, and tool function, and comparisons with open-air sites situated in the surrounding area to address issues of mobility and the organisation of hunting strategies (Bernal et al., 2003, 2005). Lithic analysis is based on the Logical Analysis System (Sistema Lógico-Analítico) of Carbonell et al. (1983, 1992, 1999; see also Thompson, 1981), which attempts to bypass the subjectivity of traditional methods.

\subsubsection{Raw materials and provenance}

We use visual observations, colorimetric determinations, thin sections of geological and archaeological samples analysed by polarised light microscopy for information on texture, mineralogy, porosity, grain size and form and fossil content, and X-ray diffraction (powder method) for mineralogical characterisation (Central 
Services of Science and Technology of the University of Cádiz; Bruker D-8 Diffractometer, $\mathrm{Cu} \mathrm{K} \alpha$ radiation). The latter shows that quartz predominates as a mineral phase present in flints, sandstones and radiolarites. We are also applying geochemical analysis by means of XRF (Central Services of Science and Technology of the University of Cádiz; Bruker-AXS Explorer equipment, Rh radiation) to help identify source areas for raw materials. The aim of these analyses is to identify catchment areas and inform on economic strategies (Chamorro et al., 2003).

\section{Results}

\subsection{Pollen}

The pollen sequence is dominated by Cedrus, and to lesser extent, Pinus, Quercus and Juniperus, Other woody elements include Olea, Ceratonia, Alnus, Salix and Ulmus (Fig. 4). The herbaceous component mainly comprises Artemisia, Asteraceae and Chenopodiaceae species. Shrubs, including heath taxa, are of minor significance. This pattern is typical of dry Mediterranean conditions, perhaps with the presence of permanent or semi-permanent bodies of water. There are, however, significant changes in vegetation composition, with a general reduction in arboreal, littoral and aquatic taxa, and a general decline in diversity over time, together with an associated increase of steppe taxa, all of which suggests a progressive decline in humidity. Another important feature is the absence in levels 1, 4, 7 and 9 of taxa associated with cold conditions, combined with changes in the structure and composition of the vegetation. Four distinctive pollen zones have been identified, which show a broad correspondence between changes in vegetation and cycles of climatic change inferred from the sediments. We further group these four pollen zones into two Cycles of vegetation change, Cycle A (pollen zones I and II) and Cycle B (pollen zones III and IV), each Cycle showing a shift from initially warm and humid conditions to drier conditions.
Zone I coincides with the Lower Cycle identified from sediments and lithology (levels 1-3), and is characterised by an absence of pollen from level 1, and a dominance of arboreal vegetation in the other levels, with Cedrus, Betula and Quercus, together with Olea, Pinus and more rarely riverine taxa. Particularly notable in this phase is the high diversity within all categories of vegetation, as well as the development of the aquatic element. Juniperus and Ericaceae co-exist with other more Mediterranean elements such as Tamarix, Rosaceae and to a lesser extent Cistaceae. The herbaceous component shows the maximum diversity, as well as the largest selection of taxa. Another important feature is the presence of Pseudoschizaea, which is suggestive of flowing water, which is not found anywhere else within the sequence (Pantaleón et al., 1996). This phase therefore describes warm conditions, corroborating the information recorded from the sediments.

Zone II, corresponding to the Middle Cycle (levels 4-6), is associated with sediments that indicate relatively mild and humid conditions, though the pollen suggests a significant decline in forest taxa, characterised by the retreat of Cedrus and the expansion of pine, the substitution of Quercus spp. by Olea and the apparent absence of temperate taxa. This is also consistent with the expansion of heathers (which are eventually replaced by Juniperus). Herbs are dominated by Asteraceae, Artemisia, Ephedra and Chenopodiaceae, and together with the absence of aquatic taxa and a significant decline in diversity, suggest drier conditions. Nonetheless, the presence of riverine taxa together with Tamarix seems to indicate the continued presence of flowing water. Both these zones make up the first large cycle (Cycle A), which is characterised by a contraction of forest, a loss in diversity and an increase in aridity.

Zone III (levels 7 and 8) sees the recovery of the vegetation, with the arrival of warmer and more humid conditions. This is reflected in the dominance of tree taxa, with the return of Quercus, Olea, Ulmus and to a lesser extent Juglans, and by the expansion of Ericaceae. Non-arboreal pollen diversity increases, but steppe taxa are rare. There is also an increase in nitrophilous taxa, such as Rumex

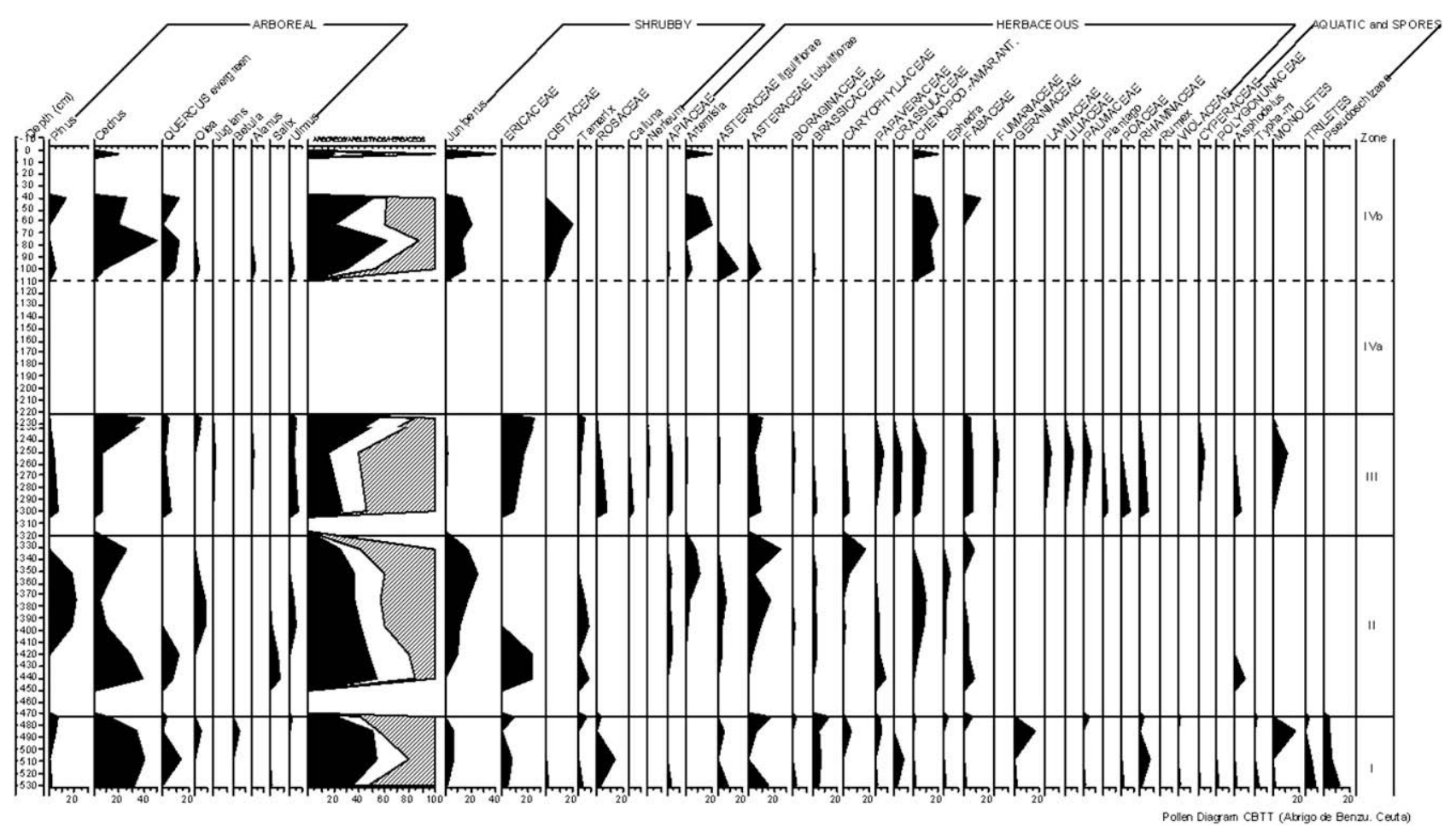

Fig. 4. Pollen diagram of Benzú rockshelter, showing detailed breakdown of arboreal, shrub and herbaceous taxa. The diagram between the arboreal and shrubby columns is a summary diagram showing, from left to right, the overall percentages of arboreal, shrubby and herbaceous pollen. 
and Plantago, as well as an increase in aquatic taxa in response to an increase in standing water. Altogether this suggests an increase in temperature as well as a significant rise in humidity.

Zone IV is made up of levels 9 and 10. From a geological point of view, level 9 represents a cold stage, which is corroborated by the absence of pollen evidence. In level 10 , however, we see the reemergence of vegetation indicating milder and more humid conditions, with the reappearance of forest taxa, the expansion of Cedrus and an increase of Olea and Quercus, together with the absence of temperate taxa and the gradual loss of riverine taxa. Ericaceae are absent and Juniperus and Cistaceae expand, together with steppe-dominated grass taxa. These data, together with the absence of aquatic elements, and the loss in diversity of taxa, indicate relatively dry conditions. Once again, these two zones define another larger cycle (Cycle B), characterised by a loss of diversity and an increase in drier conditions, similar to the previous cycle.

\subsection{Fauna}

The remains recovered during the 2002 campaign are abundant, and we have to date identified the presence of Bovidae of indeterminate genera in level 7 (Arribas, 2003). During the 2004 campaign, I. Cáceres (Universidad de Cádiz) identified in levels 5 and 6 of grid CVII a significant proportion of bones from medium-sized mammals, as well as a fragmented diaphysis of a medium-sized ungulate humerus, which shows signs of intentional fracturing and burning (Arribas et al., 2006; Ramos et al., 2006b).

At this stage in the investigation, the data suggest that the human inhabitants took advantage of all the resources available in the surrounding area, including wetlands and the rocky environment of Gebel Musa, characteristic biotopes favoured by medium-sized mammals. Taphonomic analyses of the bones-fractures and cutmarks-and studies of associations with lithic artefacts have yet to be completed.

\subsection{Lithics}

\subsubsection{Raw materials}

In level 7 , siliceous raw materials dominate, comprising sandstones, flint and radiolarites. These include grey, cream and black massive flint, ochre, grey and brown compact sandstones, and different coloured radiolarites, especially red, pink and greenish grey. In levels 6, 5 and 4, sandstone dominates, with percentages around $90 \%$ (Fig. 5A-C), and new types of flint and radiolarite are present. Thus, siliceous raw materials predominate, often of a very good quality, and there is a clear selection in the use of specific raw materials for particular types of tools (Domínguez-Bella et al., 2006). Flint and radiolarite outcrops occur in the region at Ued Zarjan, Hafa ed Dohor, Hafa Queddana and Gebel Dersa, and these are currently under study. In the carbonate formations of the Gebel Musa Group, nearby the site, there occurs an opaque radiolariteflint, reddish-lilac in colour, associated with nodular limestones of the Toarcien-Aalenien formation, and green radiolarites attributed to the Dogger-Malm (Chamorro, 2004; Domínguez-Bella, 2004). The sandstones used in the lithic industry are similar to the Belliounes flysch formation, less than $1 \mathrm{~km}$ from the Benzú site, which show an alternation of coarse quartzitic sandstones with cream, grey or brown ones (Oligocene-Aquitanien). At this stage of analysis, the lithic industries appear to have been made on local raw materials available in the immediate vicinity or in the wider region of Benzú. Retouched tools, especially Mousterian points and scrapers, show a preferential selection for flint and radiolarite.

\subsubsection{Technology and typology}

A preliminary study of the lower sequence (levels 4 to 2), together with level 7, has produced a total of 9300 lithic artefacts
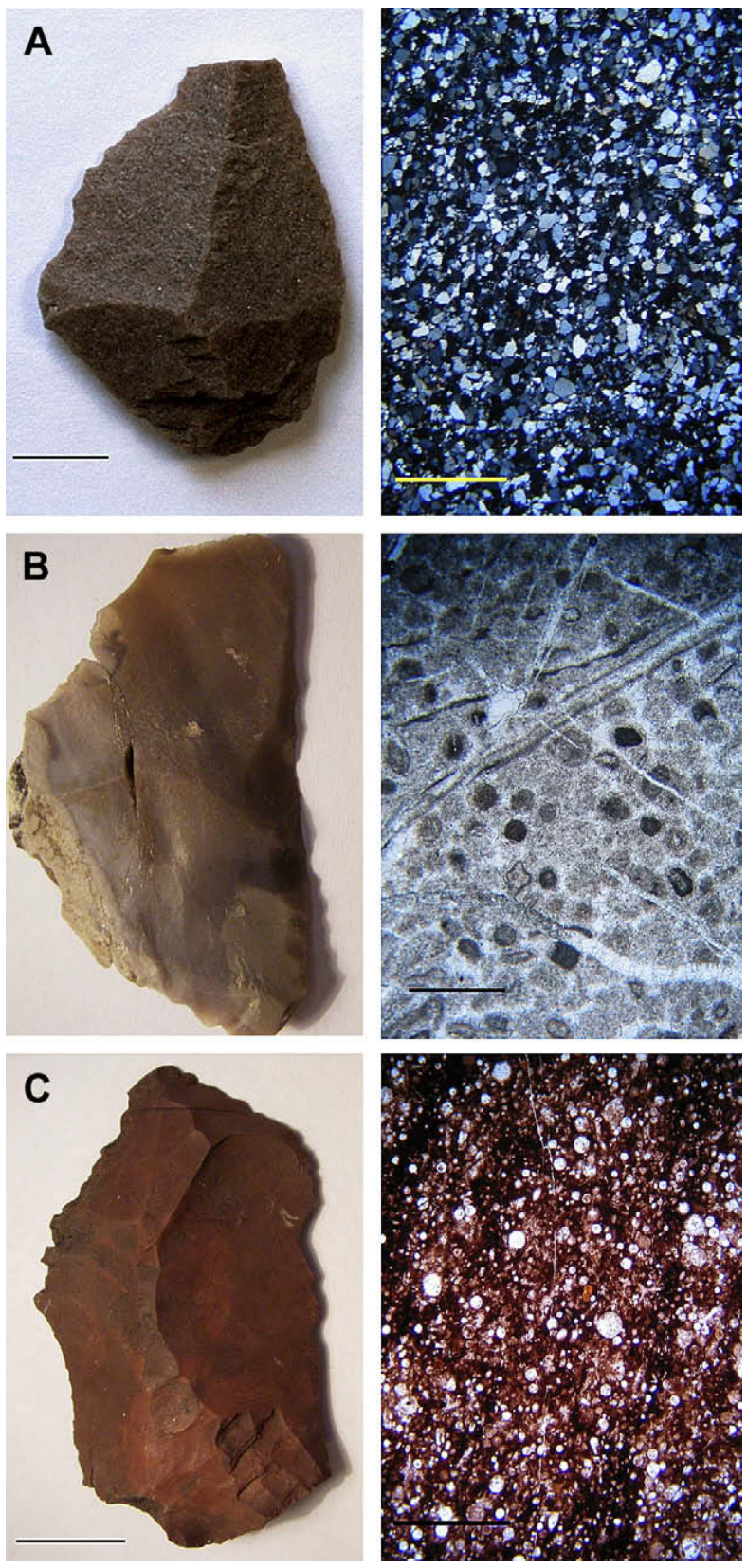

Fig. 5. Different samples of raw materials used in the lithic industry from Benzú. (A) compact sandstone; (B) massive flint; (C) red radiolarite. Macroscopic aspect is shown on the left (scale bar $=1 \mathrm{~cm}$ ) and thin section on the right (scale bars: $A=5 \mathrm{~mm}$; $\mathrm{B}, \mathrm{C}=1 \mathrm{~mm}$ ).

(Table 2). Core reduction includes unipolar, Levallois and general multi-polar centripetal techniques. Nodules were brought into the site and knapped in situ, as indicated by the presence and quantity of debitage, blanks and retouched tools. Blanks are in the form of

Table 2

Number of artefacts analysed per stratigraphic level

\begin{tabular}{lc}
\hline Level & Artefacts \\
\hline 7 & 533 \\
4C & 960 \\
4B & 352 \\
AA & 4067 \\
3B & 3303 \\
AA & 329 \\
2 & 756 \\
Total analysed & $\mathbf{9 3 0 0}$ \\
\hline
\end{tabular}




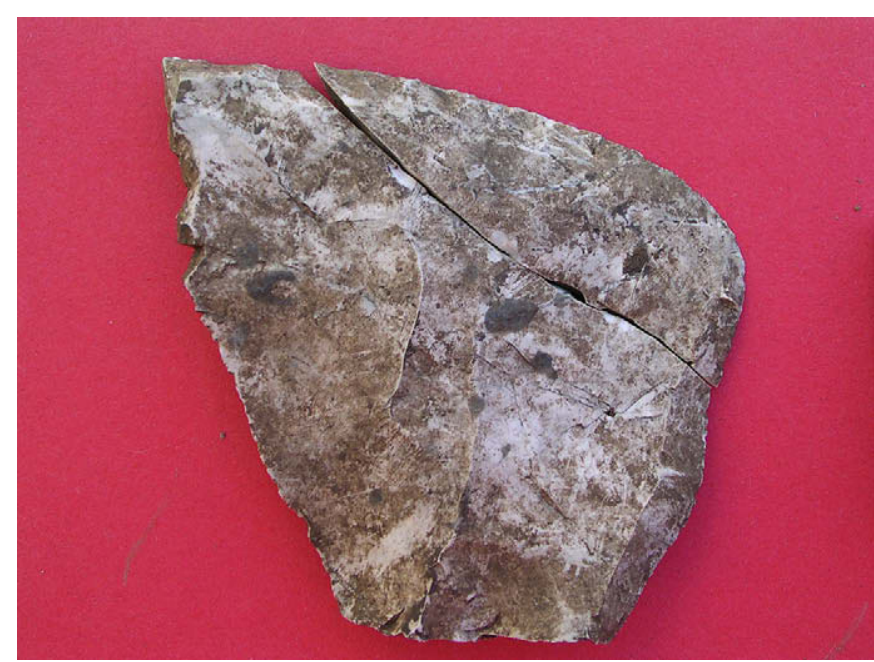

Fig. 6. Example of scraper from the BenzÚ rockshelter.

flakes, although some blades are also present indicating considerable technical ability. Retouched artefact types include a variety of scrapers: simple, double, transversal and asymmetrical (types R11, R21, R22, R23 of Laplace, 1975) (Fig. 6), Mousterian points (type P21), and, less abundantly, notches and denticulates (types D21 and D23).

\subsubsection{Use-wear}

Preliminary studies have established that microwear traces are present on the artefacts and have not been erased or obscured by contact with brecciated sediments, fire, or other post-depositional factors (Clemente, 2006). Further analysis has demonstrated a difference between level 5 and level 6 . Three scrapers recovered from level 5, made respectively on jasper, whitish-grey flint and compact sandstone or quartzite, show typical evidence of hide scraping, probably fresh hide given the low angle of the tool and limited smoothing of the working edge (Fig. 7). It has been demonstrated experimentally that both sandstone and quartzite show evidence of use-wear polish, and the wear visible on the Benzú material is typical of that produced experimentally when hide (or fat) is processed in the presence of abrasive materials, such as sand or earth (Clemente, 1997; Gibaja et al., 2002).

Three scrapers analysed from level 6, two made from sandstone, the third from flint with evidence of thermal alteration, show evidence of contact with a medium-hard material, such as wood (Fig. 8). The artefact CB-03-CVII-6-36 is particularly significant. The retouched edge (with a $55^{\circ}$ angle) has not been utilised, whereas the other side, the natural edge with an angle of $35-40^{\circ}$, is the one with evidence of use-wear. This shows that the retouched edge was not the working edge, but a blunted edge designed to avoid injury when held in the hand.

\section{Discussion}

\subsection{Pollen analysis}

The pollen results indicate predominantly warm climate conditions, with significant fluctuations in humidity, and two distinctive cycles of vegetation change, Cycle A (Zones I and II) and Cycle B (Zones III and IV). Both Cycles show a similar sequence of changes, beginning with the establishment of temperate and Mediterranean

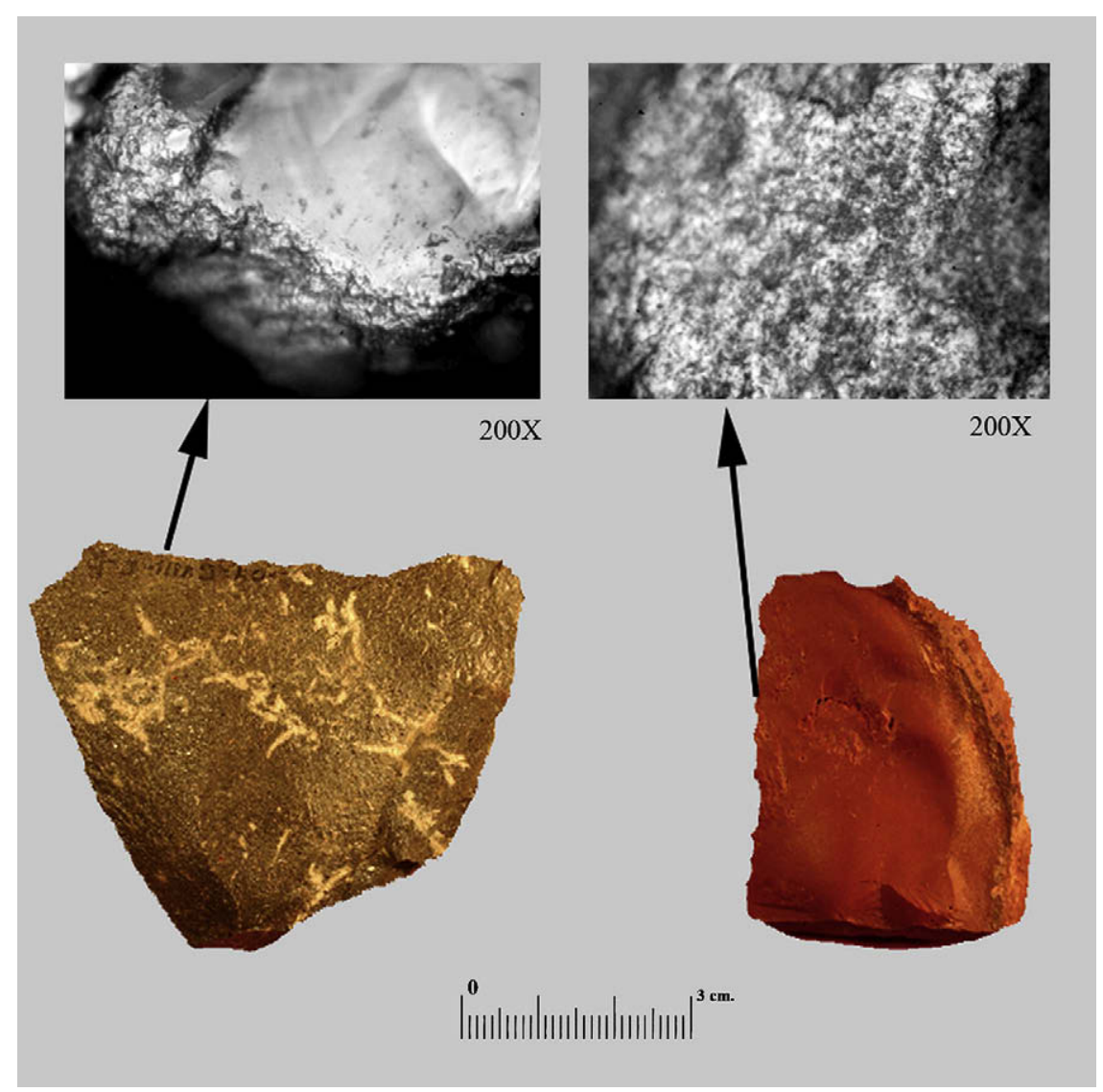

Fig. 7. Scrapers from level 5 of the Benzú rockshelter used for working hides. 


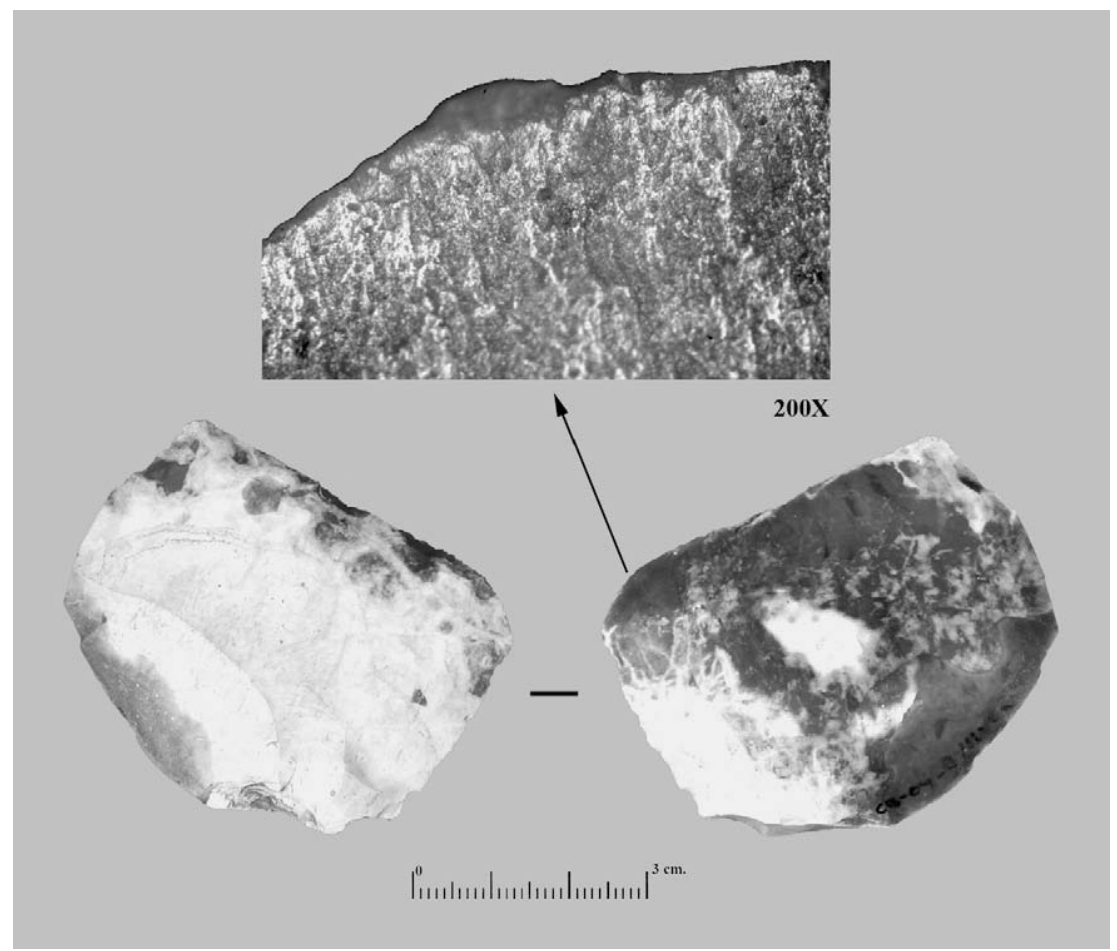

Fig. 8. Scrapers with signs of woodworking from level 6 of the Benzú rockshelter.

forest with a high diversity of shrubs and grasses, and riverine and aquatic taxa (Zones I and III), followed by a period of deforestation, the disappearance of temperate taxa and a general decline in taxonomic diversity (Zones II and IV). Each pollen zone is separated by a layer that is relatively sterile in pollen grains. We also note the effect of a progressive reduction in humidity on Mediterranean open landscapes, seen in the transitions from Cycle A to Cycle B (Ruiz Zapata and Gil García, 2003), and how this sequence of recovery/ degradation is translated into a progressive loss of diversity.

The limited evidence for cold conditions is consistent with OIS 7 or OIS 5. In spite of differences of local geography, tentative comparisons can be made with data from the Iberian Peninsula. The travertine of Horna (Ruiz Zapata et al., 2002) developed on the T4 terrace of the Henares River has a maximum date of $135 \pm 12 \mathrm{ka}$ and defines lithologically the warm conditions of OIS 5. Palynology of this deposit indicates a progressive replacement of forest, dominated by Pinus and Betula as well as other temperate taxa, indicative of a warm-humid climate, by predominantly grassy vegetation and by a more Mediterranean tree composition, including Quercus, in response to a much drier climate. The Middle Pleistocene is recorded at the archaeological sites of Salchicha Inferior and Pinedo on the Tagus River near Toledo. Pollen from Salchicha Inferior, on the $40 \mathrm{~m}$ terrace, suggests a Mediterranean climate with pulses of greater humidity and a tendency towards drier conditions (Martín Arroyo, 1998). From Pinedo, on arid land on the $30 \mathrm{~m}$ terrace, the pollen shows a reduction in temperate tree and aquatic taxa, reflecting drier conditions (Martín Arroyo et al., 1996, 1999; Ruiz Zapata et al., 2004). The pollen recovered from the peat bog of Padul in Granada (Florschütz et al., 1971; Pons and Reille, 1988) shows an erratic development of Quercus ilex forests, indicating a Mediterranean climate with a tendency towards quite humid conditions.

\subsection{Lithic technology}

The lithic material has a bearing on two issues. One is the nature of the activities carried out at the site. The combination of classic techno-typological studies with use-wear analysis shows that the activities represented by the artefacts can be identified in some cases. At present the number of artefacts analysed for their usewear is too small to indicate whether the differences between level 5 with evidence of hide-working, and level 6 with evidence of wood-working, represent a consistent trend through time or different activities carried out in different parts of the rockshelter. But the success of use-wear analysis encourages future work on larger samples.

The other issue is the question of connections across the Strait of Gibraltar (Domínguez-Bella et al., 2004; Ramos et al., 2003). The techno-typological and use-wear analyses of the lithic industry are unlikely to offer any relevant information here because similarities in this respect between different regions, although suggestive, might simply be the result of independent convergence, or diffusion of lithic traditions from a common source in the Near East rather than directly across the Strait. Analysis of raw materials, however, offers a more promising line of investigation. One difficulty, of course, is the similarity of the geological formations on either side of the Strait, and the results obtained so far from Benzú suggest that all the raw materials used on the site were obtained locally or from the African side. However, extension of such studies to a wider range of sites and raw materials, and the use of a wider range of analytical techniques capable of discriminating between distinctive mineralogical and geochemical signatures may throw more light on this issue in future.

\section{Conclusions}

The Benzú rockshelter has a sequence of deposits dated by U/Th and OSL techniques, which produce consistent results, and indicate a chronology extending from ca $250 \mathrm{ka}$ to $70 \mathrm{ka}$, the date of the speleothem formation that seals the top of the sequence. The stone tool industries throughout are of Mousterian (Mode 3) type. The stone artefacts are made on a variety of raw materials of good 
quality including quartzite and flint, which are abundantly available locally or in the wider region. There is evidence for the deliberate selection of particular raw materials for particular types of artefacts, and evidence of production, retouching and maintenance of artefacts within the site. Use-wear analyses conducted on a small number of scrapers have demonstrated working of hides and wood. The faunal remains are too fragmentary to provide specific indications beyond the presence of small and mediumsized ungulates including Bovidae. The pollen analysis describes predominantly warm conditions, with fluctuations in humidity and a long-term trend to increased aridity and reduced taxonomic diversity. The hominin species responsible for the manufacture of the Benzú material is unknown, although recent data from Gebel Irhoud suggest the association of Homo sapiens with a Mode 3 stone industry (Zouak, 2001). The site is well placed to throw light on potential connections across the Strait of Gibraltar between Africa and Europe. The stone tool industries on both sides of the Strait closely resemble each other, but this in itself is not decisive evidence for contacts, and further work on the sourcing of the raw materials used to make the stone artefacts will be required to throw more light on this issue.

\section{Acknowledgements}

This Project is the result of collaboration between the Autonomous City of Ceuta and the University of Cádiz (Project OT2006/ 217) and is part of the International Cooperation Proyects AECI A/ 2893/05 and A/6728/06, in collaboration with Dr. Ali Maate (UAE, Tetouan, Morocco) and Ramon Morán. We would like to thank Mabel Deu, Fernando Villada, Maria Teresa Troya and Gabriel Fernández for their Institutional help. We would also like to thank Paloma Uzquiano for the anthracological data, Alfonso Arribas and Isabel Cáceres for their study of the faunal assemblage, Joaquín Rodríguez-Vidal for geomorphological data from the Gibraltar area, Clive Finlayson for inviting us to contribute this paper, and to the editors for improving the English. Finally, we thank all the specialists, archaeologists, students and volunteers that have participated in the excavations and studies during the Benzú Project.

\section{References}

Abad, M., Cáceres, L.M., Rodríguez-Vidal, J., Ruiz, F., López-González, N., Chamorro, S., Bernal, D., Ramos, J., 2007. Rasgos morfológicos y bioerosivos en un alto nivel marino del Pleistoceno Medio: El Abrigo arqueológico de la Cabililla de Benzú (Ceuta). Abstracts XII Reunión Nacional de Cuaternario. AEQUA, Avila, Spain.

Arribas, A., 2003. Datos del registro faunístico del Pleistoceno del Abrigo. In: Ramos, J., Bernal, D., Castañeda, V. (Eds.), El Abrigo y la Cueva de Benzú en la Prehistoria de Ceuta. Consejería de Educación y Cultura de Ceuta, UNED Ceuta and Universidad de Cádiz, Cádiz, pp. 289-291.

Arribas, A., Ramos, J., Bernal, D., 2006. ¿Cazaban animales? In: Ramos, J., Bernal, D. (Eds.), El Proyecto Benzú 250.000 años de historia en la orilla africana del Círculo del Estrecho. 30 preguntas y 10 opiniones. Ciudad Autónoma de Ceuta and Universidad de Cádiz, Cádiz, pp. 125-126.

Bateman, M., Calado, D., 2003. Análisis por O.S.L. de dos muestras del Abrigo de Benzú. In: Ramos, J., Bernal, D., Castañeda, V. (Eds.), El Abrigo y la Cueva de Benzú en la Prehistoria de Ceuta. Consejería de Educación y Cultura de Ceuta, UNED Ceuta and Universidad de Cádiz, Cádiz, pp. 273-280.

Benéitez P. Millán, M.A. Ramos, J. Bernal, D Castañeda, V. 2004. Datación absoluta por Termoluminiscencia de material cerámico y carbonatos procedentes del yacimiento arqueológico de la Cueva de Benzú (Ceuta). In: Felíu, M.J., et al. (Eds.). Avances en Arqueometría. Universidad de Cádiz, Cádiz, pp. 17-24.

Bernal, D., 2002. La Carta Arqueológica terrestre de Ceuta. Revista de Arqueología $253,46-53$.

Bernal, D., Lorenzo, L., Castañeda, V., Ramos, J., 2003. La Carta Arqueológica de Ceuta. Historiografía y resultados de la prospección del año 2001. Registro y yacimientos prehistóricos. In: Ramos, J., Bernal, D., Castañeda, V. (Eds.), El Abrigo y la Cueva de Benzú en la Prehistoria de Ceuta. Consejería de Educación y Cultura de Ceuta. UNED Ceuta and Universidad de Cádiz, Cádiz, pp. 77-159.

Bernal, D., Castañeda, V., Ramos, J., Lorenzo, L., 2005. Novedades de la Prehistoria de Ceuta: Resultados científicos de la Carta Arqueológica. V. Jornadas de Historia de Ceuta. Ceuta desde la Prehistoria al final del Mundo Clásico. Instituto de Estudios Ceutíes, Ceuta. 9-20.

Calado, D. 2006. ¿Qué técnicas de datación se han aplicado en Benzú? In: Ramos, J., Bernal, D. (Eds.), El Proyecto Benzú 250.000 años de historia en la orilla africana del Círculo del Estrecho. 30 preguntas y 10 opiniones. Ciudad Autónoma de Ceuta and Universidad de Cádiz, Cádiz, pp. 104-106.

Carbonell, E., Guilbaud, M., Mora, R., 1983. Utilización de la lógica analítica para el estudio de tecno-complejos con cantos tallados. Cahier Noir 1, 3-64.

Carbonell, E., Mosquera, M., Ollé, A., Rodríguez, X.P., Sala, R., Vaquero, M., Vergés, J.M., 1992. New Elements of the Logical Analytic System. Tarragona.

Carbonell, E., Márquez, B., Mosquera, M., Ollé, A., Rodríguez, X.P., Sala, R., Vergés, J.M., 1999. El Modo 2 en Galería. Análisis de la industria lítica y sus procesos técnicos. In: Carbonell, $\mathrm{E}$, et al. (Eds.), Atapuerca: Ocupaciones humanas y paleoecología del yacimiento de Galería. Arqueología en Castilla y León 7, Zamora, pp. 299-352.

Clemente, I., 1997. Los instrumentos líticos de Túnel VII: una aproximación etnoarqueológica. In: Treballs d'Etnoarqueologia, 2. CSIC, Madrid.

Clemente, I., 2006. ¿Para qué se usaron esas piedras? El análisis funcional como respuesta a viejas cuestiones. In: Ramos, J., Bernal, D. (Eds.), El Proyecto Benzú. 250.000 años de historia en la orilla africana del Circulo del Estrecho. 30 preguntas y 10 opiniones. Ciudad Autónoma de Ceuta and Universidad de Cádiz, Cádiz, pp. 89-95.

Coûteaux, M., 1977. A propos de l'interprétation des analyses polliniques de sédiments minéraux principalement archéologiques on le milieu végétal, les faunes et l'homme. Supplément Bulletin Association Française pour l'Etude du Quaternaire 47, 259-276

Chamorro, S., 2004. Marco geológico del Abrigo y Cueva de Benzú. In: Ramos, J., Bernal, D., Castañeda, V. (Eds.), Investigación interdisciplinar en Humanidades. Excavaciones arqueológicas en el yacimiento de Benzú (Ceuta). XVI Edición de los Cursos de Verano de la Universidad de Granada en Ceuta, Ceuta, pp. 145-151.

Chamorro, S., Domínguez-Bella, S., Pereila, F., 2003. Geología del yacimiento de Benzú. Análisis arqueométrico de la industria lítica y las materias primas minerales. In: Ramos, J., Bernal, D., Castañeda, V. (Eds.), El Abrigo y la Cueva de Benzú en la Prehistoria de Ceuta. Consejería de Educación y Cultura de Ceuta, UNED Ceuta and Universidad de Cádiz, pp. 169-205.

Domínguez-Bella, S., 2004. Arqueometría, materias primas minerales, captación, distribución y consumo de recursos líticos en el yacimiento de Benzú, In Investigación interdisciplinar en Humanidades. Excavaciones arqueológicas en el yacimiento de Benzú (Ceuta). XVI Edición de los Cursos de Verano de la Universidad de Granada en Ceuta, Ceuta. 153-159.

Domínguez-Bella, S. Ramos Muñoz, J. Castañeda, V., García, M.E. Sánchez, M. Jurado, G., Moncayo, F., 2004. Lithic products analysis, raw materials and technology in the prehistoric settlement of the river Palmones (Algeciras, Cádiz, Spain). In: Archaeometry Session. Acts of the XIVth UISPP Congress. Lieja, Bélgica. 2001. British Archaeological Reports. (BAR) International Series 1270. Oxford, pp. 47-55.

Domínguez-Bella, S., Chamorro, S., Ramos, J., Bernal, D., 2006. Materias primas minerales y geología en el entorno del Abrigo y la Cueva de Benzú (Ceuta). In Sociedades Prehistóricas, Recursos Abióticos y Territorio. Actas III Reunión de trabajo sobre Aprovisionamiento de Recursos Abióticos en la Prehistoria. Universidad de Granada. 119-133.

Durán, J.J., 2003. Informe geológico del Abrigo de Benzú. In: Ramos, J., Bernal, D., Castañeda, V. (Eds.), El Abrigo y la Cueva de Benzú en la Prehistoria de Ceuta. Consejería de Educación y Cultura de Ceuta, UNED Ceuta and Universidad de Cádiz, Cádiz, pp. 263-266.

Durán, J.J., 2004. Estudio de los sedimentos carbonáticos asociados a cavidades kársticas. Métodos de datación, geocronológica absoluta y análisis de isótopos estables. In: Ramos, J., Bernal, D., Castañeda, V. (Eds.), Investigación interdisciplinar en Humanidades. XVI Edición de los Cursos de Verano de la Universidad de Granada en Ceuta, Ceuta, pp. 125-131.

Finlayson, C., Barton, N., Stringer, C., 2001. The Gibraltar Neanderthals and their extinction. In: Zilhao, J., Aubry, T., Carvalho, A. (Eds.), Les Premiers Hommes Modernes de la Péninsule Ibérique. Inst. Português de Arqueologia, Trabalhos de Arqueologia 17, Lisbon, pp. 117-122.

Finlayson, C., Giles Pacheco, F., Rodríguez-Vidal, J., Fa, D.A., Gutiérrez López, J.M., Santiago Pérez, A., Finlayson, G., Allue, E., Baena Preysler, J., Cáceres, I., Carrión, J.S., Fernández Jalvo, Y., Gleed-Owen, C.P., Jiménez-Espejo, F.J., López, P., López Sáez, J.A., Riquelme Cantal, J.A., Sánchez Marco, A., Giles Guzman, F., Brown, K. Fuentes, N., Valarino, C.A., Villalpando, A. Stringer, C.B., MartínezRuiz, F., Sakamoto, T., 2006. Late survival of Neanderthals at the southernmost extreme of Europe. Nature 443, 850-853.

Florschütz, F., Menéndez Amor, J., Wijmstra, T.A., 1971. Palinology of a thick Quaternary succession in southern Spain. Palaeogeography, Palaeoclimatology and Palaeoecology 10, 223-264.

Gamble, C., 2001. The Palaeolithic Societies of Europe. Cambridge University Press, Cambridge.

Garriga, J., Tarradell, M., 1951. Observaciones sobre el Pleistoceno de Marruecos (Regiones de Tetuán y Ceuta). Boletín de la Real Sociedad Española de Historia Natural 9, 99-118.

Gibaja, J.F., Clemente, I., Mir, A., 2002. Análisis funcional en instrumentos de cuarcita: el yacimiento del paleolítico superior de la Cueva de la Fuente del Trucho (Colunga, Huesca). In: Clemente, I., Risch, R., Gibaja, J.F. (Eds.), Análisis Funcional, su aplicación al estudio de sociedades prehistóricas. BAR International Series, 1073. Archaeopress, Oxford, pp. 79-86.

Goeury, C., De Beaulieu, J.L., 1979. A propos de la concentration du pollen a l'aide de la liqueur de Thoulet dans les sédiments minéraux. Pollen et Spores 21 (1-2), 239-251. 
Grimm, E.C., 1992. TILIA and TILIA-GRAPH: Pollen spreadsheet and graphics programs. 8th International Palynological Congress. Aix-en-Provence.

Laplace, G., 1975. La typologie analytique et structurale: Base rationelle d'étude des industries lithiques et osseuses. Colloques Nationaux. C.N.R.S. 932, Marseille, 91-143.

Martín Arroyo, T., 1998. Paleoclimatología y paleoambiente durante el Pleistoceno Medio y Superior en el Valle del Tajo. Doctoral Thesis, Universidad de Alcalá, Spain.

Martín Arroyo, T., Ruiz Zapata, M.B., Pérez-González, A., 1996. Paleoambiente en el valle del río Tajo durante el Pleistoceno Superior: primeros datos polínicos. In: Ramil-Rego, Fernandez-Rodriguez, Guittián, Rodriguez (Eds.), Biogeografía Pleistocena-Holocena de la Peninsula Ibérica. Santiago de Compostela, pp. 73-83.

Martín Arroyo, T., Ruiz Zapata, M.B., Pérez-González, A., Valdeolmillos, A., Dorado Valiño, M., Benito, G., Gil García, M.j., 1999. Paleoclima y Paleoambiente durante el Pleistoceno Superior y Tardiglaciar en la región central peninsular. In: Pallí, L. Roqué, C. (Eds.), Avances en el estudio del Cuaternario Español, Girona, pp. 317-324.

Mellars, P., 2006. A new radiocarbon revolution and the dispersal of modern humans in Eurasia. Nature 439, 931-935.

Moore, P., Webb, J., Collinson, M., 1991. Pollen Analysis. Blackwell Scientific Publications, Oxford.

Pantaleón, J., Pérez, R., Yll, E., Roure, J.M., 1996. El significado de Pseudoschizaea en secuencias sedimentarias de la vertiente mediterránea de la Península Ibérica e islas Baleares. Estudios Palinológicos, 101-106.

Pons, A., Reille, M., 1988. The Holocene and upper Pleistocene pollen record from Padul (Granada, Spain): a new study. Palaeogeography, Palaeoclimatology and Palaeoecology 66, 243-263.

Ramos, J., Bernal, D. (Eds.), 2006. El Proyecto Benzú 250.000 años de historia en la orilla africana del Círculo del Estrecho. 30 preguntas y 10 opiniones. Ciudad Autónoma de Ceuta and Universidad de Cádiz, Cádiz.

Ramos, J., Bernal, D., Castañeda, V. (Eds.), 2003. El Abrigo y la Cueva de Benzú en la Prehistoria de CeutaCiudad Autónoma de Ceuta. UNED Ceuta y Universidad de Cádiz, Cádiz.

Ramos, J., Domínguez-Bella, S., Castañeda, V., 2006a. Siliceous materials of the hunter-gatherer settlements from the Atlantic Band of Cádiz (SW Spain) in the Upper Pleistocene. Der Anschnitt 19, 531-544.

Ramos, J., Bernal, D., Durán, J.J., Domínguez-Bella, S., Ruiz, B., Gil, M.J., Calado, D. Cáceres, I., Juliá, R., Chamorro, S., 2006b. El Abrigo y la Cueva de Benzú (Ceuta).
Una secuencia del Pleistoceno Medio, Superior y Holoceno en el Norte de África. In: Sanchidrián, J.L., Márquez, A.M., Fullola, J.M. (Eds.), IV Simposio de Prehistoria Cueva de Nerja. La Cuenca Mediterránea durante el Paleolítico Superior. Fundación Cueva de Nerja, Málaga, pp. 176-189.

Rodríguez-Vidal, J., Cáceres, L.M., 2005. Evidencias morfológicas erosivas de niveles marinos pleistocenos en la costa del Jbel Musa (N. de Marruecos). In: Rodríguez-Vidal, J., Finlayson, C., Giles Pacheco, F. (Eds.), Cuaternario Mediterráneo y poblamiento de Homínidos. Gibraltar Museum and AEQUA, Gibraltar, pp. $48-49$.

Rodríguez-Vidal, J., Cáceres, L.M., Finlayson, C., Gracia, F.J., Martínez Aguirre, A. 2004. Neotectonics and shoreline history of the Rock of Gibraltar, southern Iberia. Quaternary Science Reviews 23, 2017-2029.

Ruiz Zapata, M.B., Gil García, M.J., 2003. Estimación de la vegetación del perfil del Abrigo de Benzú. In: Ramos, J., Bernal, D., Castañeda, V. (Eds.), El abrigo y la Cueva de Benzú en la Prehistoria de Ceuta. Consejería de Educación y Cultura de Ceuta. UNED Ceuta and Universidad de Cádiz, pp. 281-287.

Ruiz Zapata, M.B., Pérez-Gónzalez A Gil García, MJ. Valdeolmillos, A Dorado, M. 2002. La formación travertínica de Horna (Guadalajara): análisis polínico e interpretación paleoclimática. In: Carrasco, F., Duran, J.J., Andreo, B. (Eds.), Karst and Environments, pp. 447-452.

Ruiz Zapata, M.B., Dorado, M., Valdeolmillos, A., Gil García, M.J., Martín Arroyo, T, Pérez-Gónzalez, A, 2004. Registro paleoambiental y paleoclimático del Pleistoceno Medio y Superior en depósitos fluviales del valle del río Tajo (Toledo). Zona Arqueológica. Miscelánea en homenaje a Emiliano Aguirre. 506-517.

Stringer, C., Gamble, C., 1993. Solving the Puzzle of Human Origins. Thames and Hudson, London.

Thompson, E.P., 1981. Miseria de la teoría. Editorial Crítica, Barcelona.

Uzquiano, P., 2006. ¿Qué es la Antracología? Métodos de muestreo, Análisis e interpretación de las maderas carbonizadas en Prehistoria. Aplicación al estudio de los carbones de Benzú. In: Ramos, J., Bernal, D. (Eds.), El Proyecto Benzú 250.000 años de historia en la orilla africana del Círculo del Estrecho. 30 preguntas y 10 opiniones. Ciudad Autónoma de Ceuta and Universidad de Cádiz, Cádiz, pp. 109-115.

Zouak, M., 2001. Origine et évolution de l'Homme au Maghreb 'Hypothèses diverses'. In Actes des 1ères Journées Nationales d'Archéologie et du Patrimoine, Rabat, 154-156. 